B. Carmona et al.

[AQ1]

\title{
Environmental Action Scale: psychometric properties of the Portuguese version (Escala de Acciones
} Ambientales: propiedades psicométricas de la versión portuguesa)

\author{
Beatriz Carmona ${ }^{\underline{a}}$, Ana Loureiro $\underline{\underline{b}}$ and M. Carmen Aguilar-Luzón ${ }^{\underline{a}}$ \\ aUniversidad de Granada; ${ }^{\mathrm{a} U n i v e r s i d a d e ~ L u s o ́ f o n a ~ d e ~ L i s b o a ~}$ \\ English version: pp. XX-XX / Versión en español: pp. XX-XX \\ References / Referencias: pp. XX-XX \\ Translation from English/Traducción del inglés: Miguel del Río \\ CONTACT M. Carmen Aguilar-Luzón maguilarluzon@ugr.es Escuela de Psicología, \\ Universidad de Granada, Campus de Cartuja, Granada 18071, España
}

Received 13 March 2019

Accepted 13 November 2020

\begin{abstract}
The Environmental Action Scale (EAS) is an 18-item questionnaire designed to assess the degree of involvement in collective actions in favour of the environment. This scale is of interest for research in environmental domains, particularly the recent study of environmental activism. The main objective of this study is to contribute to the adaptation and validation of the Portuguese version of the EAS. The EAS Portuguese version - following its adaptation — was administered to a total of 346 participants. Confirmatory factor analysis revealed the two dimensions considered by the authors of the original version: participatory actions and leadership actions. In addition, evidence of validity was obtained based on the relationship with other variables such as environmental identity. In conclusion, the Portuguese version maintains the 18 items and replicates the two-factor structure, showing good psychometric properties.
\end{abstract}

\section{KEYWORDS}

validation; collective environmental actions; environmental identity; EAS; EACA RESUMEN

La Escala de Acciones Ambientales (Environmental Action Scale, EAS) es un cuestionario de 18 ítems diseñado para evaluar el grado de implicación en acciones 
colectivas a favor del medio ambiente. Esta escala es interesante para la investigación en dominios medioambientales, en concreto para el estudio reciente del activismo medioambiental. El objetivo principal de este estudio es contribuir a la adaptación y validación de la versión portuguesa de la EAS. La versión portuguesa de la EAS (después de su adaptación) se administró a un total de 346 participantes. El análisis factorial confirmatorio reveló las dos dimensiones contempladas por los autores de la versión original: acciones participativas y acciones de liderazgo. Además, se obtuvieron pruebas de su validez, a partir de la relación con otras variables como la identidad ambiental. En conclusión, la versión portuguesa mantiene los 18 ítems y replica la estructura bifactorial, mostrando buenas propiedades psicométricas.

\section{PALABRAS CLAVE}

validación; acciones ambientales colectivas; identidad ambiental; EAS; EACA

Alisat and Riemer (2015) define collective actions as conscious and intentional actions that aim to reduce environmental problems, as well as promote those aspects related to the defence of the environment through collective efforts. These authors designed The Environmental Action Scale (EAS), an 18-item questionnaire aimed at evaluating the degree of involvement of people in collective actions in favour of the environment. This scale was later used by these same authors in an intervention programme, the Youth Leading Environmental Change (YLEC; Riemer et al., 2016), for university students from Bangladesh, Canada, Germany, India, Uganda and the United States, in order to encourage students to engage in these types of environmental actions. As a main result they found that the majority of participants experienced a significant personal transformation, both in terms of how they perceive themselves as agents of change and how they relate to environmental problems.

Recently, given the absence of a scale for measuring these characteristics in the Spanish population, and with the intention of developing intervention programmes similar to the YLEC in different universities of this country, the adaptation and validation of the Spanish version of the EAS has been carried out. This validation, with a sample of 286 participants from the general population (EACA, Carmona-Moya et al., 2019), resulted in a scale which consisted of 16 items, compared to the 18 of the EAS, and presented good psychometric properties, confirming the two construct dimensions of the original version: Participation Activities and Leadership Activities.

Alisat and Riemer (2015) consider that collective environmental actions can be placed on a continuum, so that at one extreme we would find participatory actions, simple behaviours carried out by the population such as staying informed on environmental issues, and/or discussing these issues with others. That is, it encompasses 
actions that do not require high involvement and that entail relatively little social or political pressure. And at the other extreme we would find leadership activities. Many people never go beyond simple participatory actions, whereas others come to assume leadership roles such as those of organizing events and creating groups for the defence of the environment (leadership actions).

Both the research carried out by Carmona-Moya et al. (2019) and that by Alisat and Riemer (2015) support the notion of an association between involvement in environmental collective actions and the scores obtained on other scales that measure similar constructs. For example, the scores on the EAS and the EACA have been positively and significantly associated with those obtained on the Environmental Identity Scale (Clayton, 2003) in both studies. This result confirms that collective environmental actions and environmental identity are two closely associated constructs (Whitmarsh \& O’Neill, 2010). In a similar vein, other studies have attempted to identify other factors that are related to, or act as a background to, collective action, as is the case of environmental attitudes considered in the work conducted by Routhe et al. (2005) as a predictor of the intention to engage in pro-environmental behaviour. Moreover, Dono et al. (2010) found a strong relationship between individual proenvironmental behaviour and environmental activism.

It should be noted that in addition to the EAS, there are other instruments available for evaluating collective environmental actions. For instance, the General Social Survey Environmental Battery (GSS, Davis \& Smith, 1993) examines the structure and functioning of society by means of items that evaluate general beliefs and that involve different situations related to collective actions of various kinds, including environmental actions. Specifically, the GSS evaluates, through three items, the intention to participate in environmental activism or the willingness of people to sacrifice their welfare for the protection of the environment, although it is not a specific measure of collective environmental action but rather collective actions in general.

In Portugal, the environmental movement began mainly at the end of the seventies with the fight against nuclear energy, although the level of collective action was relatively low, since most actions were either individual or disconnected (Barca \& Delicado, 2016; Soromenho-Marques, 2005). Only in the eighties to nineties did the environmental movement begin to gather momentum with the creation of several 
environmental NGOs in the country, most of which had a local or regional focus. In the middle of the nineties, the country still had a poor level of public participation and involvement in environmental issues; only two in 1,000 had an environmental NGO affiliation. Presently, this level of participation is still incipient, since in 2018 only $2.9 \%$ of the population supported an environmental NGO and $4.4 \%$ signed a petition for an environmental cause (Loureiro et al., 2019). Despite this general lack of association culture, there are some NGOs that developed a consistent influence in some areas and specific cases (Soromenho-Marques, 2005). This activity combines the approach on broader issues (e.g., climate change and energy policies) with involvement in local issues (e.g., co-incineration or ore extraction). Further, more recently, and following the phenomena seen in other countries such as the Transition movement, there are some community-based initiatives that provide evidence of some actual active engagement in tackling climate change challenges (Fernandes-Jesus et al., 2017). Nonetheless, political authorities still fail to encourage effective public participation in environmental issues (Barca \& Delicado, 2016).

Given the lack of specific instruments for evaluating collective behaviour in the environmental field, we believe it is necessary to develop specific scales and measures for this type of action, such as those of the EAS and the EACA. For the most part, environmental behaviour scales tend to evaluate specific behaviours that have an impact on the environment, and they generally focus on individual behaviours (e.g., Kaiser, 1998). In addition, we must point out that adequate instruments are not available in the literature to measure collective environmental actions in the Portuguese context. For this reason, the main objective of this study is to contribute towards the adaptation and validation of the Portuguese version of the EAS, as well as to confirm its two-factor structure in a Portuguese sample.

\section{Method}

\section{Participants and instruments}

The EAS scale was translated into Portuguese by a Portuguese-English-Spanish trilingual Portuguese researcher. Subsequently, two other Portuguese researchers verified the suitability of the adaptation to the original version in English. The translated English version, compared to the original (Alisat \& Riemer, 2015), proved to be 
semantically equivalent. Therefore, we conclude that the Portuguese version of the EAS is equivalent to the original version in English, composed, like the original scale, of 18 items with a Likert-type response format with five response options ranging from 0 ('never') and 4 ('frequently') (see Appendix 1).

The Portuguese version of the EAS was administered to a total of 346 participants, of which $20.5 \%(N=71)$ were men and $79.5 \%$ were women $(N=275)$. The participants were of Portuguese nationality, with an age range between 17 and 73 years $(M=28.48, S D=12.39)$. Of these, $91 \quad(26.3 \%)$ said they considered themselves activists in environmental matters, compared to 233 (67.3\%) who said they did not, whilst $22(6.4 \%)$ did not respond to this question. The average number of hours of weekly participation in environmental activities for the total sample was 3.79 $(S D=9.18)$, with the mean for the group that considered themselves to be activists being $8.57(S D=13.03)$, which is relatively high in comparison with the group that did not consider themselves to be active in environmental matters $(M=1.86, S D=6.10)$.

In addition to EAS, other instruments were administered to obtain information on the relationship between environmental collective actions and other related constructs that have been described above, that is, environmental identity and environmental attitude, in order to test the convergent validity of EAS. Likewise, to find evidence of discriminant validity, a scale of individual environmental behaviour or personal practice was used to confirm the possibility of empirically dealing with different scales. This was carried out according to the hypothesis of the authors of the original version, who argue that the actions considered in the EAS are of a collective nature and are focused beyond the individual, so they differ from personal or individual practice and therefore constitute, in this case, different constructs.

\section{Environmental Behaviour Scale (EBS)}

In order to evaluate individual environmental behaviour or personal practice, we used a Portuguese scale consisting of 11 items, the first seven of which were adapted from a study by Milfont and Duckitt (2004), with the remaining four items being taken from a study conducted by Zhao et al. (2014) adapted to Portuguese in the work of Gomes (2015). The Cronbach's Alpha values obtained in the original studies were .77 and .78, 
respectively. The scale specifically measures various individual behaviours, such as recycling, reuse, green purchasing and civic behaviour. Specifically, the participants were asked to indicate the frequency with which they had engaged in these behaviours in the past year, using a five-point Likert scale ('Never', 'Rarely', 'Occasionally', 'Frequently' and 'Very often').

\section{New Ecological Paradigm (NEP)}

In order to measure environmental attitudes, we decided to include the scale of the New Ecological Paradigm, developed by Dunlap and Van Liere (1978) and updated by Dunlap et al. (2000), but in its Portuguese version adapted by Castro (2006), which consists of 15 items (e.g., 'We are approaching the limit of the number of people that the Earth can support'), with a five-point Likert-type response format ranging from 1 ('strongly disagree') to 5 ('very much in agreement').

\section{Environmental Identity Scale (EID)}

We used a Portuguese translation of the Environmental Identity Scale (Clayton, 2003), also adapted to Spanish by Olivos and Aragonés (2011). This scale is composed of 24 items (e.g., 'I spend a lot of time in natural environments - forests, mountains, lake, sea') with a five-point Likert-type response format ranging from 1 ('strongly disagree') to 5 ('very much in agreement').

\section{Procedure}

The questionnaires were distributed both online, through the Google Forms survey platform and various other means such as social networks, forums, email and text messages, as well as on paper in different classrooms of the Lusófona University in Lisbon. The participants were informed of the confidentiality clauses and gave their consent before responding to the items. The average response time of the participants was 15 minutes. This research was approved by the Ethics Committee of the University 
of Granada (Spain).

Later, based on the responses collected, we checked the reliability of the EAS through an analysis of internal consistency, along with the other scales considered, whilst the psychometric properties of the items were assessed using the Discrimination Index $(D I)$. In addition, evidence of convergent validity was obtained based on the internal structure and the relationship with other variables. The internal structure was evaluated by means of a Confirmatory Factor Analysis (CFA) where the adjustment between the theoretical model underlying the original scale and the empirical data obtained in the Portuguese sample was checked. All data were analysed with the Jamovi software.

\section{Results}

First, given that the sample used in this study is unbalanced in terms of the number of men and women, in order to check whether this composition could affect the results obtained, we compared the mean scores of the Portuguese version of the EAS between the men and women of the sample. The results indicate that there are no statistically significant differences between men and women, $(t(344)=1.123 ; p=.262)$.

The reliability of each scale was analysed to evaluate internal consistency. The results showed adequate reliability values $(\alpha>.70)$ for all scales administered, and specifically, the EAS Portuguese version showed adequate internal consistency $(\alpha=.93)$. Table 1 displays the descriptive data for each of the scales.

The analysis of the psychometric properties of the EAS items revealed values of $D I$ (discrimination index) higher than .40 in all cases, which confirmed that the items discriminated adequately between people with high and low scores on the scale. The items of the EAS scale obtained DI values ranging between .54 (Item 12) and .80 (Item 8). Table 2 shows the items and the obtained $D I$ values.

Later, the internal structure was evaluated by means of a Confirmatory Factorial Analysis (CFA) where the adjustment between the theoretical model underlying the original scale and the empirical data obtained in the Portuguese sample was checked. We followed the same steps as those used by Alisat and Riemer (2015) in the process of validating the original scale (EAS). Like the authors of the original scale, we considered 
the cut-offs proposed by other researchers for a good fit of the model, where the relative chi-square should be less than 2 or 3 (Kline, 2005), the RMSEA less than .08 ( $\mathrm{Hu} \&$ Bentler, 1995) and the CFI greater than .93 (Byrne, 1994). The CFA for the proposed model, with a general collective action factor and two sub-factors (participation activities and leadership actions), shows an adequate adjustment $\left(X^{2}=369, d f=126\right.$, $X^{2} / d f=2.92$, Bollen-Stine bootstrap $\left.X^{2} p=.001 ; C F I=.93 ; R M S E A=.07\right)$ after adding the covariance between the errors of the following pairs of items: $1-4,1-5,2-3,4-5,9-$ $10,11-15,13-12$ and $6-5$.

Therefore, these results provide support for the proposed two-factor scale structure, one composed of items that assess active environmental leadership and another that represents participation activities. The standardized estimates of the factorial loads of the two secondary factors in the main factor of general environmental commitment were high in the study of the original version, and this was also the case in the present study; the standardized estimate for 'leadership actions' was $.90(.71$ in the original version), and the standardized estimate for 'participatory actions' was .96 (1.20 in the original version). The standardized estimates of the factor loadings of the items on the two secondary factors were between .48 and .82 (see Figure 1).

The relationships with other variables were examined by analysing the correlations between EAS and the rest of the scales administered (EID, NEP and EBS). Convergent validity was evaluated by comparing the scores obtained on the EAS with those of the EBS, EDI and NEP scales. The results showed that the scores on the EAS correlated significantly with those of the $\operatorname{EBS}(r=.59, p<.001)$ and with Environmental Identity $(r=.45, p<.001)$, but only moderately with the NEP $(r=.24$, $p<.001)$.

Finally, in order to conduct an analysis of predictive validity of the scale, also known as group-validity, we focused on a subgroup of the sample, i.e., those who consider themselves to be environmental activists $(N=91)$. The mean EAS score for this sample was $1.41(S D=1)$, significantly higher $(t=10.74, d f=322, p<.001)$ than the mean score of the sample that do not consider themselves to be environmental activists $(M=0.52, S D=0.47)$, even though this sample is larger than the previous one. The same pattern of results was observed when we compared both groups in terms of the two dimensions of the scale, with the activists showing higher scores $(M=1.87$, 
$S D=1.06 ; M=0.82, S D=1.04)$ than the non-activists $(M=0.82, S D=0.62 ; M=0.16$, $S D=0.35)$ in both participatory actions $(t=10.98, d f=322, p<.001)$ and leadership actions $(t=8.53 d f=322, p<.001)$. Therefore, the predictive validity of the scale is supported.

\section{Discussion}

The main objective of this paper was to present the adaptation of the EAS developed by Alisat and Riemer (2015) to the Portuguese context and to evaluate its psychometric properties. For this, we used the 18 items that comprise the original scale, translated into Portuguese. This new adapted version of the EAS contributes towards an advancement in research and can be of use for future research that aims to study the personal level of involvement in collective actions.

The administration of the EAS confirmed the factorial structure of the original scale in the Portuguese sample, and, subsequently, evidence of reliability and validity (convergent and discriminant) was obtained to support its usefulness for evaluating the collective environmental actions in this population. In particular, the EAS-PT reports a general factor on Environmental Collective Action and two second-order factors corresponding to the dimensions of Leadership actions and Participation actions. At the same time, EAS-PT has been shown to be significantly associated with other related scales (EBS, EID and NEP).

Thus, collective environmental action, as a general construct measured by EASPT, reflects the level of involvement of people in civic, intentional and conscious behaviours that seek to alleviate the systemic causes of environmental problems and promote environmental sustainability through collective efforts. And, at the same time, the EAS-PT allows us to evaluate both participation in simple collective environmental actions, which are included in the so-called dimension of participative actions, and engagement in behaviours associated with leading the environmental actions of other people, that is, the so-called leadership actions dimension.

Alisat and Riemer (2015) argue that those who engage in collective environmental actions are not necessarily those who are also involved in individual behaviours, since these may be motivated by other non-environmental reasons, such as 
social norms or economic savings. However, unlike these authors, we expected that the mean scores obtained on the EAS-PT would be related to those obtained on the individual environmental behaviour scale (Dono et al., 2010). Support for this suggestion comes from the results obtained in the present study, which indicate that people who engage in individual pro-environmental behaviours also show significant levels of involvement in collective environmental actions, and vice versa.

Similarly, the scores on the EAS-PT showed a positive and significant association with those obtained on the Environmental Identity Scale (Clayton, 2003), supporting the idea that collective environmental actions and environmental identity are two closely associated constructs (Alisat \& Riemer, 2015; Carmona-Moya et al., 2019; Whitmarsh \& O'Neill, 2010). However, the moderate association between EAS-PT and NEP suggests that high scores on pro-environmental attitudes do not necessarily entail a high degree of involvement in environmental actions. This may be due to the fact that in modern society, attitudes towards the environment have been - and continue to be the focus of educational programmes, and these attitudes have thus become increasingly common and homogeneous among the general population, as is also the case for the present sample.

Finally, it is worth noting that since the number of women included in the sample in this study was higher than the number of men, we considered the possibility that this particularity of the sample could affect the EAS scores in some way, since some studies have found gender-related differences in the various antecedents of environmental behaviour (Calvo-Salguero et al., 2014; Ruiz et al., 2018). Thus, we decided to clarify how this composition could affect our data. Whilst there seems to be some consensus in the literature regarding the greater sensitivity of women to environmental issues, differences in most of the aspects analysed, when compared with men, are not significant from a statistical standpoint (Castells \& Morey, 2004). The presents results are in line with these findings. In conclusion, we believe that this scale provides a useful tool in the context of environmental research. It allows for the development of studies aimed at analysing the determinant, predictive, mediator or moderator factors of collective environmental actions and how these relate to other variables. This scale may also be useful in studies where information is obtained on the similarities and differences between different types of pro-environmental behaviours on an individual or 
group level. Perhaps most importantly, the EAS-PT is an appropriate tool for the development of research concerned with public engagement in collective environmental action issues in Portugal and other Portuguese-speaking countries, and might even be of value in comparative studies conducted across various countries using different versions of the EAS.

Escala de Acciones Ambientales: propiedades psicométricas de la versión portuguesa

Alisat y Riemer (2015) definen las acciones colectivas como acciones conscientes e intencionales que persiguen la reducción de los problemas ambientales, así como fomentar aquellos aspectos relativos a la defensa del medio ambiente mediante esfuerzos colectivos. Estos autores diseñaron la Escala de Acciones Ambientales (Environmental Action Scale, EAS), formada por 18 ítems dirigidos a la evaluación del grado de implicación de las personas en acciones colectivas a favor del medio ambiente. Los mismos autores usaron posteriormente esta escala en un programa de intervención, denominado, Juventud que Lidera el Cambio Medioambiental (Youth Leading Environmental Change, YLEC; Riemer et al., 2016) destinado a estudiantes universitarios de Bangladesh, Canadá, Alemania, India, Uganda, y los Estados Unidos, con el fin de animar a los estudiantes a participar en este tipo de acciones medioambientales. Como resultado principal, encontraron que la mayoría de participantes experimentaron una transformación personal significativa, tanto en términos de cómo se percibían a sí mismos como agentes para el cambio, como en la forma en que se relacionaban con los problemas medioambientales.

Recientemente, dada la falta de una escala para medir estas características en la población española, y con la intención de desarrollar programas de intervención similares al YLEC, se llevó a cabo la adaptación y validación de la versión española de la EAS. Esta validación, con una muestra de 286 participantes de la población general (EACA, Carmona-Moya et al., 2019), resultó en una escala que consistía de 16 ítems, en comparación a los 18 de la EAS, y presentaba buenas propiedades psicométricas, confirmando las dos dimensiones de constructo de la versión original: Actividades Participativas y Actividades de Liderazgo.

Alisat y Riemer (2015) consideran que las acciones ambientales colectivas pueden situarse en un continuo, de tal manera que en un extremo encontraríamos las 
acciones participativas, comportamientos simples como mantenerse informados sobre temas medioambientales, y/o hablar de estos temas con otras personas. Esto es, incluye acciones que no requieren una alta implicación y que conllevan relativamente poca presión social o política. Y en el otro extremo, encontraríamos las actividades de liderazgo. Muchas personas nunca van más allá de las simples acciones participativas, mientras que otras asumen roles de liderazgo, como la organización de eventos y la creación de grupos para la defensa del medio ambiente (acciones de liderazgo).

Las investigaciones llevadas a cabo tanto por Carmona-Moya et al. (2019) como por Alisat y Riemer (2015) apoyan la idea de que existe una asociación entre la implicación en acciones ambientales colectivas y las puntuaciones obtenidas en otras escalas que miden constructos próximos o relacionados. Por ejemplo, las puntuaciones en la EAS y la EACA se han asociado positiva y significativamente con las obtenidas en la Escala de Identidad Ambiental (Environmental Identity Scale, Clayton, 2003) en ambos estudios. Este resultado confirma que las acciones ambientales colectivas y la identidad ambiental son dos constructos estrechamente relacionados (Whitmarsh \& O’Neill, 2010). De manera similar, otros estudios han intentado identificar otros factores que están relacionados con, o que actúan de trasfondo de la acción colectiva, como es el caso de las actitudes ambientales que, según el trabajo de Routhe et al. (2005), se consideran predictores de la intención de involucrarse en comportamientos proambientales. Además, Dono et al. (2010) encontraron una fuerte relación entre el comportamiento proambiental individual y el activismo medioambiental.

Debe subrayarse que, además de la EAS, existen otros instrumentos disponibles para la evaluación de las acciones ambientales colectivas. Por ejemplo, la Batería Ambiental de la Encuesta Social General (General Social Survey Environmental Battery, GSS, Davis \& Smith, 1993) examina la estructura y funcionamiento de la sociedad mediante ítems que evalúan creencias generales, y que atañen a diferentes situaciones relacionadas con acciones colectivas de diversa índole, incluyendo las acciones ambientales. En concreto, la GSS evalúa, mediante tres ítems, las intenciones de participar en el activismo medioambiental, o la predisposición de las personas a sacrificar su propio bienestar por la protección del medio ambiente, si bien no se trata de una medida específica de acción ambiental colectiva, sino de acciones colectivas en general. 
En Portugal, el movimiento ambientalista comenzó fundamentalmente a finales de los años 70, con la lucha contra la energía nuclear, aunque el nivel de acción colectiva era relativamente bajo, siendo la mayoría de acciones de tipo individual (Barca \& Delicado, 2016; Soromenho-Marques, 2005). Solo en los años 80 y los 90 comenzó a ganar importancia el movimiento medioambiental, con la creación de varias ONGs medioambientales en el país, la mayoría de las cuales tenía un énfasis local o regional. A mediados de los 90, la participación pública y la implicación en los temas medioambientales era aún pobre: solo dos de cada 1,000 personas se había afiliado a alguna ONG medioambiental. En la actualidad, este nivel de participación es aún incipiente, ya que en 2018 solo un $2.9 \%$ de la población apoyaba una ONG medioambiental, y $4.4 \%$ había firmado una petición por una causa medioambiental (Loureiro et al., 2019). Pese a esta falta general de cultura asociativa, algunas ONGs han desarrollado una influencia consistente en algunas áreas o en casos concretos (Soromenho-Marques, 2005). Esta actividad combina un enfoque en temas amplios (por ejemplo, cambio climático y políticas energéticas) con la implicación en temas locales (por ejemplo, co-incineración o extracción de mena). Además, más recientemente han surgido algunas iniciativas comunitarias que aportan pruebas de alguna implicación activa real en el abordaje de los desafíos del cambio climático (Fernandes-Jesus et al., 2017). No obstante, las autoridades políticas aún fracasan a la hora de fomentar la participación pública efectiva en los temas medio ambientales (Barca \& Delicado, 2016).

Dada la falta de instrumentos específicos para la evaluación del comportamiento colectivo en el campo ambiental, creemos que es necesario desarrollar escalas y medidas específicas para este tipo de acción, como la EAS y la EACA. En su mayor parte, las escalas de comportamiento ambiental tienden a evaluar comportamientos específicos que tienen un impacto sobre el medio ambiente, y por lo general se centran en los comportamientos individuales (por ejemplo, Kaiser, 1998). Además, debemos apuntar que, para el contexto portugués, no se encuentra en la literatura instrumentos adecuados para medir acciones medioambientales colectivas.

Método<<t/s: Head1 $>>$

Participantes e instrumentos $<<$ t/s: Head2>> 
Un investigador trilingüe (portugués-inglés-español) tradujo la EAS al portugués. A continuación, otros dos investigadores portugueses verificaron la adecuación de la adaptación a la versión original en inglés. La versión traducida del inglés, en comparación con la original (Alisat \& Riemer, 2015), demostró ser semánticamente equivalente. Por lo tanto, concluimos que la versión portuguesa de la EAS es equivalente a la versión original en inglés, y está compuesta, como la escala original, por 18 ítems con un formato de respuesta tipo Likert, con cinco opciones de respuesta que oscilan entre el 0 ('nunca') y el 4 ('a menudo') (ver Apéndice 1).

La versión portuguesa de la EAS se administró a 346 participantes, de los que $20.5 \%(N=71)$ eran hombres y el $79.5 \%$ mujeres $(N=275)$. Los participantes eran de nacionalidad portuguesa, con un rango de edad entre 17 y 73 años $(M=28.48$, $D T=12.39)$. De ellos, $91(26.3 \%)$ dijeron considerarse activistas en temas ambientales, frente a los $233(67.3 \%)$ que dijeron no serlo, mientras que $22(6.4 \%)$ no respondieron a esta pregunta. El número medio de horas de participación semanal en actividades ambientales para el total de la muestra era de $3.79(D T=9.18)$, siendo la media para el grupo que se consideraban activistas de $8.57(D T=13.03)$, lo cual es relativamente alto en comparación con el grupo que no se consideraba activo en cuestiones ambientales $(M=1.86, D T=6.10)$.

Además de la EAS, se administraron otros instrumentos para obtener información sobre la relación entre las acciones colectivas ambientales y otros constructos relacionados y descritos más arriba, esto es, identidad ambiental y actitud ambiental, a fin de comprobar la validez convergente de la EAS. Igualmente, para encontrar pruebas de validez discriminante, se empleó una escala de comportamiento ambiental individual o práctica personal para confirmar la posibilidad de manejar distintas escalas empíricamente. Esto se realizó de acuerdo con la hipótesis de los autores de la versión original, que argumentan que las acciones tenidas en cuenta en la EAS son de naturaleza colectiva y se enfocan más allá del individuo, de manera que difieren de la práctica individual o personal y en este caso, por tanto, constituyen distintos constructos.

\section{Escala de Conducta Ambiental (Environmental Behavior Scale, EBS)}

Para evaluar la conducta ambiental individual o las prácticas personales, empleamos una escala portuguesa formada de 11 ítems; los primeros siete fueron adaptados de un estudio de Milfont y Duckitt (2004), y los cuatro restantes se tomaron de un estudio de 
Zhao et al. (2014) adaptado al portugués en el trabajo de Gomes (2015). Los valores del alfa de Cronbach obtenidos en los estudios originales era de .77 y .78 , respectivamente. La escala mide específicamente diversas conductas individuales, como el reciclaje, la reutilización, las compras verdes y el comportamiento cívico. En concreto, se pidió a los participantes que indicaran la frecuencia con la que habían llevado a cabo estas conductas en el último año, empleando una escala tipo Likert de cinco puntos ('Nunca', 'Rara vez', 'Ocasionalmente', 'Con frecuencia' y 'Muy a menudo').

\section{Nuevo Paradigma Ecológico (New Ecological Paradigm, NEP)}

Para medir las actitudes ambientales, decidimos incluir la escala del Nuevo Paradigma Ecológico, desarrollada por Dunlap y Van Liere (1978) y actualizada por Dunlap et al. (2000), pero en su versión portuguesa, adaptada por Castro (2006), que consiste de 15 ítems (por ejemplo, 'Estamos llegando al límite del número de personas que puede albergar la Tierra'), con un formato de respuesta tipo Likert de cinco puntos que oscila entre 1 ('muy en desacuerdo') y 5 ('muy de acuerdo').

\section{Escala de Identidad Ambiental (Environmental Identity Scale, EID)}

Empleamos la traducción portuguesa de la Escala de Identidad Ambiental (Environmental Identity Scale, Clayton, 2003), también adaptada al español por Olivos

y Aragonés (2011). Esta escala se compone de 24 ítems (por ejemplo, 'Paso mucho tiempo en entornos naturales — bosques, montañas, lagos, mar-'), con un formato de respuesta tipo Likert de cinco puntos, entre 1 ('muy en desacuerdo') y 5 ('muy de acuerdo').

\section{Procedimiento $<<\mathrm{t} / \mathrm{s}:$ Head2 $>>$}

Ambos cuestionarios se distribuyeron online, mediante la plataforma de encuestas Google Form, y otros medios diversos como redes sociales, foros, correo electrónico y mensajes de texto, así como en papel en diferentes aulas de la Universidad Lusófona de Lisboa. Se informó a los participantes de las cláusulas de confidencialidad, y dieron su 
consentimiento antes de responder a los ítems. El tiempo medio de respuesta de los participantes fue de 15 minutos. Esta investigación recibió la aprobación del Comité de Ética de la Universidad de Granada (España).

A continuación, y en base a las respuestas obtenidas, comprobamos la fiabilidad de la EAS mediante un análisis de consistencia interna, junto con las otras escalas empleadas, mientras que las propiedades psicométricas de los ítems se evaluaron empleando el Índice de Discriminación (ID). Además, se obtuvieron pruebas de la validez convergente en base a la estructura interna y la relación con otras variables. La estructura interna se evaluó mediante un Análisis Factorial Confirmatorio (Confirmatory Factor Analysis, CFA), en el que se comprobó el ajuste entre el modelo teórico que subyace a la escala original y los datos empíricos obtenidos en la muestra portuguesa. Todos los datos se analizaron con el software Jamovi.

\section{Resultados $<<$ t/s: Head1 $>>$}

En primer lugar, dado que la presencia de hombres y mujeres en la muestra empleada en este estudio está desequilibrada, y con el fin de comprobar si esta composición muestral podría afectar a los resultados obtenidos, comparamos las puntuaciones medias de la versión portuguesa de la EAS de las mujeres y los hombres de la muestra. Los resultados indican que no hay diferencias estadísticamente significativas entre hombres y mujeres $(t(344)=1.123 ; p=.262)$.

Se analizó la fiabilidad de cada escala para evaluar la consistencia interna. Los resultados muestran valores de fiabilidad adecuados $(\alpha>.70)$ para todas las escalas administradas $\mathrm{y}$, en concreto, la versión portuguesa de la EAS mostró consistencia interna adecuada $(\alpha=.93)$. En la Tabla 1 se pueden ver los datos descriptivos para cada una de las escalas.

El análisis de las propiedades psicométricas de los ítems de la EAS mostró valores de $I D$ (índice de discriminación) superiores a .40 para todos los casos, lo que confirma que los ítems discriminan adecuadamente entre puntuaciones altas y bajas en la escala. Los ítems de la EAS obtuvieron valores de $I D$ que oscilaban entre .54 (Ítem 12) y .80 (Ítem 8). La Tabla 2 muestra los ítems y los valores $I D$ obtenidos.

A continuación, se evaluó la estructura interna mediante un Análisis Factorial Confirmatorio (Confirmatory Factorial Analysis, CFA) en el que se comprobó el ajuste entre el modelo teórico subyacente a la escala original y los datos empíricos obtenidos 
de la muestra portuguesa. Seguimos los mismos pasos empleados por Alisat y Riemer (2015) en el proceso de validación de la escala original (EAS). Como los autores de la escala original, tuvimos en cuenta los puntos de corte propuestos por otros investigadores para acordar un buen ajuste del modelo, según los cuales el chi cuadrado relativo debería ser inferior a 2 o 3 (Kline, 2005), la RMSEA inferior a .08 ( $\underline{\mathrm{Hu}}$ \& Bentler, 1995), y el CFI mayor que .93 (Byrne, 1994). El CFA para el modelo propuesto, con un factor general de acción colectiva y dos sub-factores (actividades participativas y acciones de liderazgo $)$ muestra un ajuste adecuado $\left(X^{2}=369, g l=126\right.$, $X^{2} / g l=2.92$, muestreo repetitivo Bollen-Stine $X^{2} p=.001 ; C F I=.93 ; R M S E A=.07$ ) después de añadir la covarianza entre los errores de los siguientes pares de ítems: 1-4, $1-5,2-3,4-5,9-10,11-15,13-12$ у $6-5$.

Por lo tanto, estos resultados apoyan la estructura propuesta de dos factores, uno compuesto de ítems que evalúan el liderazgo medioambiental activo y otro que representa las actividades de participación. Las estimaciones estandarizadas de las cargas factoriales de los dos factores secundarios en el factor principal de compromiso medioambiental general eran altas en el estudio de la versión original, y este es también el caso del presente estudio; la estimación estandarizada para 'acciones de liderazgo' era de .90 (.71 en la versión original), y la estimación estandarizada para 'acciones participativas' era de .96 (1.20 en la versión original). Las estimaciones estandarizadas de las cargas factoriales de los ítems en los dos factores secundarios estaban entre $.48 \mathrm{y}$ .82 (ver Figura 1).

Las relaciones con otras variables se estudiaron analizando las correlaciones entre la EAS y el resto de escalas administradas (EID, NEP, y EBS). La validez convergente se evaluó comparando las puntuaciones obtenidas en la EAS con las de la EBS, EDI y NEP. Los resultados muestran que las puntuaciones en la EAS correlacionaban significativamente con las de la EBS $(r=.59, p<.001)$, y con la identidad ambiental $(r=.45, p<.001)$, pero solo moderadamente con la NEP $(r=.24, p<.001)$.

Por último, para llevar a cabo un análisis de validez predictiva de la escala, también conocido como validez de grupos conocidos, nos centramos en un subgrupo de la muestra, aquellos que se consideraban a sí mismos activistas medioambientales $(N=91)$. La puntuación media EAS para esta muestra fue de $1.41(D T=1)$, significativamente más alta $(t=10.74, d f=322, p<.001)$ que la puntuación media de la 
muestra de participantes que no se consideraban a sí mismos activistas medioambientales $(M=0.52, D T=0.47)$, aunque esta muestra es mayor que la anterior. Cuando se compararon ambos grupos respecto a las dos dimensiones de la escala, se observó el mismo patrón de resultados: los activistas mostraron puntuaciones más altas $(M=1.87, D T=1.06 ; M=0.82, D T=1.04)$ que los no activistas $(M=0.82, D T=0.62 ;$ $M=0.16, D T=0.35)$ tanto en acciones participativas $(t=10.98, g l=322, p<.001)$ como acciones de liderazgo $(t=8.53 \mathrm{gl}=322, p<.001)$. Por tanto, los resultados apoyan la validez predictiva de la escala.

\section{Discusión $<<$ t/s: Head1 $>>$}

El objetivo principal de este artículo era presentar la adaptación de la EAS desarrollada por Alisat y Riemer (2015) al contexto portugués, y evaluar sus propiedades psicométricas. Para ello, empleamos los 18 ítems que componen la escala original, traducidos al portugués. Esta nueva versión adaptada de la EAS contribuye a un avance de la investigación, y puede emplearse para futuras investigaciones que persigan estudiar el nivel personal de implicación en acciones colectivas ambientales.

La administración de la EAS confirmó la estructura factorial de la escala original en la muestra portuguesa y, también, se obtuvieron pruebas de la fiabilidad y la validez (convergente y discriminante) que apoyan su utilidad para la evaluación de las acciones colectivas medioambientales en esta población. En concreto, la EAS-PT muestra un factor general de Acción Colectiva Ambiental, y dos factores de segundo orden, correspondiendo a las dimensiones de acciones de Liderazgo y acciones Participativas. Al mismo tiempo, la EAS-PT ha mostrado estar asociada significativamente con otras escalas relacionadas (EBS, EID, NEP).

Por lo tanto, la acción colectiva ambiental, como un constructo general medido por la EAS-PT, refleja el nivel de implicación de las personas en conductas cívicas, intencionales y conscientes que persiguen aliviar las causas sistémicas de los problemas ambientales y fomentar la sostenibilidad ambiental mediante esfuerzos colectivos. Y, al mismo tiempo, la EAS-PT nos permite evaluar tanto la participación en acciones ambientales colectivas simples, que se incluyen en la llamada dimensión de acciones participativas, como la implicación en conductas asociadas con el liderazgo de acciones ambientales de otras personas, esto es, la llamada dimensión de acciones de liderazgo. 
Alisat y Riemer (2015) argumentan que aquellos que se implican en acciones ambientales colectivas no son necesariamente aquellos que también se implican en conductas individuales, ya que estas pueden estar sustentadas en otros motivos no ambientales, como las normas sociales o el ahorro económico. Sin embargo, al contrario que estos autores, esperábamos que las puntuaciones medias obtenidas en la EAS-PT estuvieran relacionadas con las obtenidas en la escala de conducta ambiental individual (Individual Environmental Behavior Scale; Dono et al., 2010). Los resultados obtenidos en el presente estudio apoyan esta idea, ya que indican que las personas que se implican en comportamientos individuales proambientales también muestran niveles significativos de implicación en acciones ambientales colectivas, y viceversa.

De manera similar, las puntuaciones en la EAS-PT mostraron una asociación positiva y significativa con las obtenidas en la Escala de Identidad Ambiental (Environmental Identity Scale, Clayton, 2003), lo que apoya la idea de que las acciones ambientales colectivas y la identidad ambiental son dos constructos íntimamente asociados (Alisat \& Riemer, 2015; Carmona-Moya et al., 2019; Whitmarsh \& O’Neill, 2010). Sin embargo, la asociación moderada entre la EAS-PT y la NEP sugiere que las puntuaciones altas en actitudes proambientales no conllevan necesariamente un alto grado de implicación en acciones ambientales. Esto puede deberse al hecho de que, en la sociedad moderna, las actitudes hacia el medio ambiente han sido (y continúan siendo) el foco de los programas educativos, y estas actitudes se han ido haciendo así más habituales y homogéneas en la población general, como también ha sucedido con la muestra de este estudio.

Por último, vale la pena apuntar que, dado que el número de mujeres incluidas en la muestra de este estudio era más alto que el de hombres, tuvimos en cuenta la posibilidad de que esta particularidad de la muestra pudiera afectar a las puntuaciones en la EAS de alguna manera, ya que algunos estudios han encontrado diferencias relativas al sexo en los diversos antecedentes de la conducta ambiental (Calvo-Salguero et al., 2014; Ruiz et al., 2018). Por tanto, decidimos aclarar cómo esta composición podía afectar a nuestros datos. Mientras que parece haber algún consenso en la literatura respecto a la mayor sensibilidad de las mujeres a cuestiones medioambientales, las diferencias en la mayoría de aspectos analizados, cuando se comparan con los hombres, no son significativas desde un punto de vista estadístico (Castells \& Morey, 2004). Los 
presentes resultados están en línea con estas investigaciones. En conclusión, pensamos que esta escala aporta una herramienta útil al contexto de la investigación ambiental. Permite el desarrollo de estudios que persigan el análisis de los factores determinantes, predictivos, mediadores o moderadores de las acciones ambientales colectivas, y cómo estos se relacionan con otras variables. Esta escala también puede ser útil en estudios que obtengan información sobre las similitudes y diferencias entre distintos tipos de conductas proambientales al nivel individual o grupal. Y quizá lo más importante es que la EAS-PT es una herramienta adecuada para el desarrollo de investigaciones relacionadas con la implicación pública en temas relativos a la acción ambiental colectiva en Portugal y otros países de habla portuguesa, y pueda incluso ser valiosa en estudios comparativos llevados a cabo en diversos países empleando distintas versiones de la EAS.

\section{Acknowledgements / Agradecimientos}

This research has been funded by the Project 'Environmental Identity Model of environmental collective actions (EIMECA)', granted in the call for Pre-Competitive Research Programs for Young Researchers of the Independent Research and Transfer Plan of the University of Granada (Spain), reference (PPJIB2018-04). This study was carried out through a collaboration between two prestigious universities, the Lusófona University of Lisbon (Portugal) and the University of Granada (Spain), and is part of the doctoral thesis of Beatriz Carmona Moya, called 'Environmental Identity Model of Environmental Collective Actions'. We are particularly grateful to anonymous collaborators for the translation and revision of the scale. / Esta investigación ha recibido fondos del proyecto 'Modelo de Identidad Ambiental de Acciones Ambientales Colectivas' (Environmental Identity Model of environmental collective actions, EIMECA), concedido en el Programa de Investigación Pre-Competitivo para Investigadores Jóvenes del Plan Propio de Investigación del Vicerrectorado de Investigación y Transferencia de la Universidad de Granada (España), referencia (PPJIB2018-04). El presente estudio se llevó a cabo en colaboración entre dos universidades de prestigio, la Universidad Lusófona de Lisboa (Portugal) y la Universidad de Granada (España), y es parte de la tesis doctoral de Beatriz Carmona Moya, bajo el título de 'Modelo de Identidad Ambiental de Acciones Ambientales 
Colectivas'. Agradecemos especialmente a los colaboradores anónimos por la traducción y revisión de la escala.

\section{Disclosure statement / Conflicto de intereses[AQ2]}

No potential conflict of interest was reported by the authors. / Los autores no han referido ningún potencial conflicto de interés en relación con este artículo.

\section{References / Referencias}

Alisat, S., \& Riemer, M. (2015). The environmental action scale: Development and psychometric evaluation. Journal of Environmental Psychology, 43, 13-23.

https://doi.org/10.1016/j.jenvp.2015.05.006[AQ3]

Barca, S., \& Delicado, A. (2016). Anti-nuclear mobilisation and environmentalism in Europe: A view from Portugal (1976-1986). Environment and History, 22(4), 497-520. https://doi.org/10.3197/096734016X14727286515736

Byrne, B. M. (1994). Structural equation modeling with EQS and EQS/windows. Sage Publications.

Calvo-Salguero, A., Aguilar-Luzón, M. C., Salinas, J. M., \& García, J. M. A. (2014). Gender, masculinity and femininity as ecocentrism and anthropocentrism predictors. Psyecology: Bilingual Journal of Environmental Psychology, 5(2-3), 284-316. https://doi.org/10.1080/21711976.2014.942509 Carmona-Moya, B., Benítez, I., \& Aguilar-Luzón, M. C. (2019). Psychometric properties of the Spanish version of the Environmental Action Scale (EAS)/Propiedades psicométricas de la versión española de la Escala de Acción Colectiva Ambiental (EACA). Revista De Psicología Social (International Journal of Social Psychology), 34(2), 256-280. https://doi.org/10.1080/02134748.2019.1576322 Castells, M., \& Morey, M. (2004). La percepcion de los problemas ambientales y la vision del futuro en los jovenes españoles [Paper presented]. VII CONAMA. Madrid. http://www.conama.org/documentos/1763.pdf Castro, P. (2006). Applying social psychology to the study of environmental concern and environmental worldviews: Contributions from the social representations approach. Journal of Community and Applied Social Psychology, 16(4), 247-266.

https://doi.org/10.1002/casp.864

Clayton, S. (2003). Environmental identity: A conceptual and an operational definition. In S. Clayton \& S. Opotow (Eds.), Identity and the natural environment. The 
psychological significance of nature (pp. 45-65). Massachusetts Institute of Technology.

Davis, J. A., \& Smith, T. W. (1993). General social surveys, 1972-1993: Cumulative codebook. National Opinion Research Corporation.

Dono, J., Webb, J., \& Richardson, B. (2010). The relationship between environmental activism, pro-environmental behaviour and social identity. Journal of Environmental Psychology, 30(2), 178-186. https://doi.org/10.1016/j.jenvp.2009.11.006

Dunlap, R. E., \& Van Liere, K. D. (1978). The "new environmental paradigm". The Journal of Environmental Education, 9(4), 10-19.

https://doi.org/10.3200/JOEE.40.1.19-28

Dunlap, R. E., Van Liere, K. D., Mertig, A. G., \& Jones, R. E. (2000). New trends in measuring environmental attitudes: Measuring endorsement of the new ecological paradigm: A revised NEP scale. Journal of Social Issues, 56(3), 425-442.

https://doi.org/10.1111/0022-4537.00176

Fernandes-Jesus, M., Carvalho, A., Fernandes, L., \& Bento, S. (2017). Community engagement in the transition movement: Views and practices in Portuguese initiatives. Local Environment: The International Journal of Justice and Sustainability, 22(12), 1546-1562. https://doi.org/10.1080/13549839.2017.1379477

Gomes, A. M. (2015). Afetos e comportamento ambiental: Um estudo empírico [Master dissertation]. Universidade de Coimbra.

Hu, L. T., \& Bentler, P. M. (1995). Evaluating model fit. In R. H. Hoyle (Ed.), Structural equation modeling: Concepts, issues and applications (pp. 76-99). Sage.

Kaiser, F. (1998). A general measure of ecological behavior. Journal of Applied Social Psychology, 28(5), 395-442. https://doi.org/10.1111/j.1559-1816.1998.tb01712.x

Kline, R. B. (2005). Principles and practice of structural equation modeling. Guildford Press.

Loureiro, A., Casaca, J., Rosa, C. A., Gomes, A., \& Rousseau, J. (2019, March). Índice Nacional do Consumo Consciente: Observatório do Consumo Consciente. Communication presented at the Omnichannel Retail Show. Lisbon, Portugal. Milfont, T. L., \& Duckitt, J. (2004). The structure of environmental attitudes: A firstand second-order confirmatory factor analysis. Journal of Environmental Psychology, 24(3), 289-303. https://doi.org/10.1016/j.jenvp.2004.09.001 
Olivos, P., \& Aragonés, J. I. (2011). Propiedades psicométricas de la Escala de Identidad Ambiental (EID). Psyecology, 2(1), 15-24.

https://doi.org/10.1174/217119711794394671

Riemer, M., Voorhees, C., Dittmer, L., Alisat, S., Alam, N., Sayal, R., Bidisha, S. H., De Souza, A., Lynes, J., Metternich, A., Mugagga, F., \& Schweizer-Ries, P. (2016). The youth leading environmental change project: A mixed-method longitudinal study across six countries. Ecopsychology, 8(3), 174-187.

https://doi.org/10.1089/eco.2016.0025

Routhe, A. S., Jones, R. E., \& Feldman, D. L. (2005). Using theory to understand public support for collective actions that impact the environment: Alleviating water supply problems in a nonarid biome. Social Science Quarterly, 86(4), 874-897.

https://doi.org/10.1111/j.0038-4941.2005.00361.x

Ruiz, C., Marrero, R., \& Hernández, B. (2018). Influence of emotions on the acceptance of an oil drilling project. Environment and Behavior, 50(3), 324-349.

https://doi.org/10.1177/0013916517701795

Soromenho-Marques, V. (2005). Raízes do Ambientalismo em Portugal. In V.

Soromenho-Marques (Ed.), Metamorfoses: Entre o colapso e o desenvolvimewnto sustentável (pp. 127-144). Publicações Europa América.

Whitmarsh, L., \& O’Neill, S. (2010). Green identity, green living? The role of proenvironmental self-identity in determining consistency across diverse proenvironmental behaviours. Journal of Environmental Psychology, 30(3), 305-314. https://doi.org/10.1016/j.jenvp.2010.01.003

Zhao, -H.-H., Gao, Q., Wu, Y.-P., Wang, Y., \& Zhu, X.-D. (2014). What affects green consumer behavior in China? A case study from Qingdao. Journal of Cleaner Production, 63, 143-151. https://doi.org/10.1016/j.jclepro.2013.05.021[AQ4]

Appendix 1. EAS - PT.

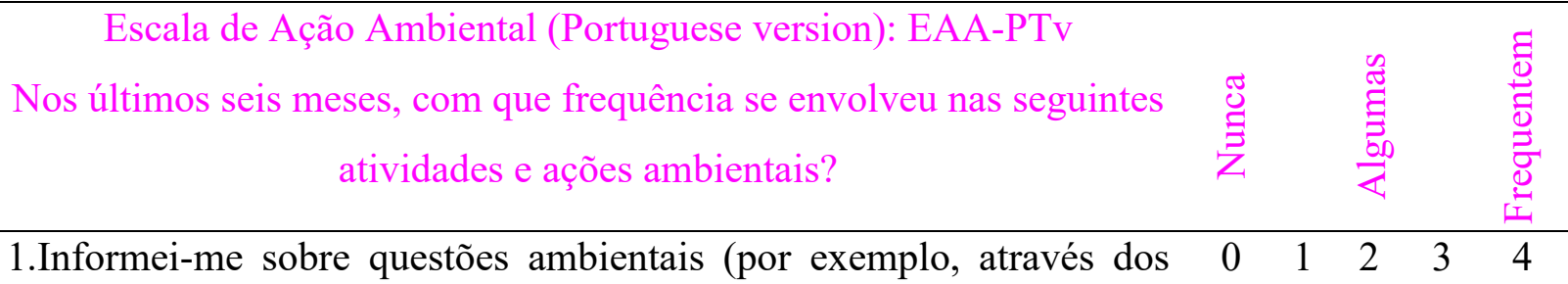
media, televisão, internet, blogs, etc.) 
Escala de Ação Ambiental (Portuguese version): EAA-PTv

Nos últimos seis meses, com que frequência se envolveu nas seguintes

atividades e ações ambientais?

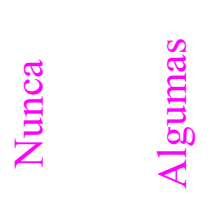

2. Participei num evento educacional (por exemplo, workshop) relacionado com o ambiente.

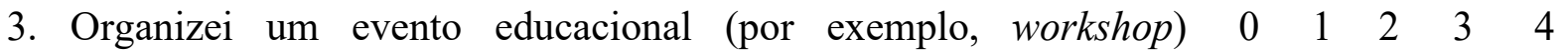
relacionado com questões ambientais.

4. Conversei com outras pessoas sobre questões ambientais (por $\begin{array}{llllll}0 & 1 & 2 & 3 & 4\end{array}$ exemplo, cônjuge, parceiro, pai(s), filhos ou amigos).

5. Usei ferramentas on-line (por exemplo, YouTube, Facebook, $\begin{array}{llllll}0 & 1 & 2 & 3 & 4\end{array}$ Wikipedia, MySpace ou blogs) para consciencializar sobre questões ambientais.

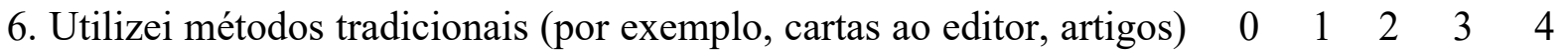
para consciencializar sobre questões ambientais.

7. Escrevi pessoalmente ou telefonei a um político/funcionário do $\begin{array}{llllll}0 & 1 & 2 & 3 & 4\end{array}$ governo sobre uma questão ambiental. (por exemplo, para pedir informação, denunciar uma situação, etc)

8. Envolví-me com um grupo ambientalista ou um partido político (por $\begin{array}{llllll}0 & 1 & 2 & 3 & 4\end{array}$ exemplo, como voluntário, trabalho de verão, etc.).

9. Apoiei financeiramente uma causa ambiental.

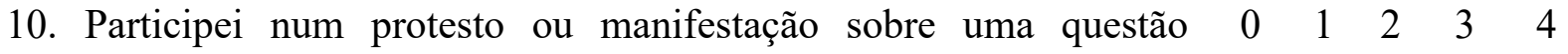
ambiental.

11. Organizei um protesto ou manifestação ambiental.

$\begin{array}{lllll}0 & 1 & 2 & 3 & 4\end{array}$

12. Organizei um boicote contra uma empresa envolvida em práticas $\begin{array}{llllll}0 & 1 & 2 & 3 & 4\end{array}$ prejudiciais ao ambiente.

13. Organizei uma petição (incluindo petições on-line) por uma causa $\quad \begin{array}{lllll}0 & 1 & 2 & 3 & 4\end{array}$ ambiental.

14. Organizei o meu tempo para poder trabalhar em questões $\begin{array}{llllll}0 & 1 & 2 & 3 & 4\end{array}$ ambientais (por exemplo, trabalhando em part-time para ter tempo para as atividades ambientais, trabalhando num trabalho ambiental, ou escolhendo atividades ambientais em detrimento de outras atividades de lazer). 

Escala de Ação Ambiental (Portuguese version): EAA-PTV
Nos últimos seis meses, com que frequência se envolveu nas seguintes
atividades e ações ambientais?

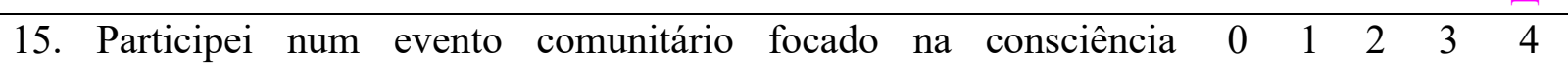
ambiental (por exemplo, limpeza de praias, bosques, etc.).

16. Organizei um evento comunitário focado na consciência ambiental. $\quad \begin{array}{llllll}0 & 1 & 2 & 3 & 4\end{array}$ 17. Participei em actividades de conservação da natureza (por $0 \begin{array}{lllllll}0 & 1 & 2 & 3 & 4\end{array}$ exemplo, plantação de árvores, restauração de cursos de água).

18. Dediquei tempo a trabalhar com um grupo/organização que lida $\begin{array}{llllll}0 & 1 & 2 & 3 & 4\end{array}$ com a relação do ambiente com outras questões sociais, como justiça ou pobreza.

Apéndice 1. EAS - PT.

Escala de Ação Ambiental (Portuguese version): EAA-PTv Nos últimos seis meses, com que frequência se envolveu nas seguintes atividades e ações ambientais?

1.Informei-me sobre questões ambientais (por exemplo, através dos media, televisão, internet, blogs, etc.)

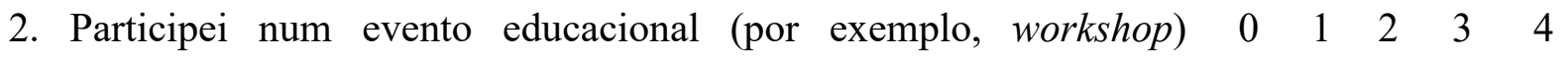
relacionado com o ambiente.

3. Organizei um evento educacional (por exemplo, workshop) relacionado com questões ambientais.

4. Conversei com outras pessoas sobre questões ambientais (por $\begin{array}{llllll}0 & 1 & 2 & 3 & 4\end{array}$ exemplo, cônjuge, parceiro, pai(s), filhos ou amigos).

5. Usei ferramentas on-line (por exemplo, YouTube, Facebook, $\begin{array}{llllll}0 & 1 & 2 & 3 & 4\end{array}$ Wikipedia, MySpace ou blogs) para consciencializar sobre questões ambientais.

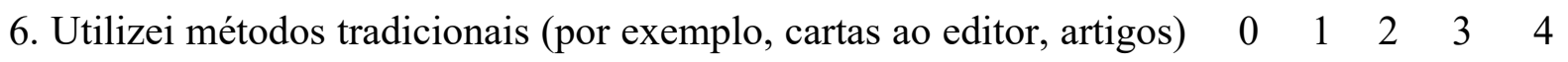
para consciencializar sobre questões ambientais.

7. Escrevi pessoalmente ou telefonei a um político/funcionário do $\begin{array}{llllll}0 & 1 & 2 & 3 & 4\end{array}$ governo sobre uma questão ambiental. (por exemplo, para pedir 
Escala de Ação Ambiental (Portuguese version): EAA-PTv

Nos últimos seis meses, com que frequência se envolveu nas seguintes

atividades e ações ambientais?

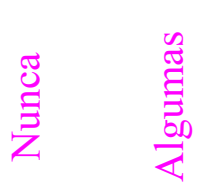

informação, denunciar uma situação, etc)

8. Envolví-me com um grupo ambientalista ou um partido político (por $\begin{array}{llllll}0 & 1 & 2 & 3 & 4\end{array}$ exemplo, como voluntário, trabalho de verão, etc.).

9. Apoiei financeiramente uma causa ambiental.

10. Participei num protesto ou manifestação sobre uma questão $\begin{array}{llllll}0 & 1 & 2 & 3 & 4\end{array}$ ambiental.

11. Organizei um protesto ou manifestação ambiental.

$\begin{array}{lllll}0 & 1 & 2 & 3 & 4\end{array}$

12. Organizei um boicote contra uma empresa envolvida em práticas $\begin{array}{llllll}0 & 1 & 2 & 3 & 4\end{array}$ prejudiciais ao ambiente.

13. Organizei uma petição (incluindo petições on-line) por uma causa $\quad \begin{array}{lllll}0 & 1 & 2 & 3 & 4\end{array}$ ambiental.

14. Organizei o meu tempo para poder trabalhar em questões $\begin{array}{llllll}0 & 1 & 2 & 3 & 4\end{array}$ ambientais (por exemplo, trabalhando em part-time para ter tempo para as atividades ambientais, trabalhando num trabalho ambiental, ou escolhendo atividades ambientais em detrimento de outras atividades de lazer).

15. Participei num evento comunitário focado na consciência $\begin{array}{llllll}0 & 1 & 2 & 3 & 4\end{array}$ ambiental (por exemplo, limpeza de praias, bosques, etc.).

16. Organizei um evento comunitário focado na consciência ambiental. $\quad \begin{array}{lllll}0 & 1 & 2 & 3 & 4\end{array}$

17. Participei em actividades de conservação da natureza (por $\begin{array}{llllll}0 & 1 & 2 & 3 & 4\end{array}$ exemplo, plantação de árvores, restauração de cursos de água).

18. Dediquei tempo a trabalhar com um grupo/organização que lida $\begin{array}{llllll}0 & 1 & 2 & 3 & 4\end{array}$ com a relação do ambiente com outras questões sociais, como justiça ou pobreza.

Figure 1. Path diagram of confirmatory factor analysis of original factor structure and factor loadings. (PA = Participatory Actions; LA = Leadership Actions). 
Figura 1. Diagrama de Trayectorias del Análisis Factorial Confirmatorio de la estructura factorial original y cargas factoriales $(\mathrm{PA}=$ Acciones Participativas; $\mathrm{LA}=$ Acciones de Liderazgo).

Table 1. Descriptive statistics for the scales.

\begin{tabular}{lllllll}
\hline Scale & $N$ items & Minimum & Maximum & $M$ & $S D$ & $A$ \\
\hline EAS-PT & 18 & 0.00 & 3.94 & 0.76 & 0.75 & .93 \\
EBS & 11 & 1.18 & 5.00 & 3.43 & 0.75 & .83 \\
NEP & 15 & 2.87 & 5.00 & 4.00 & 0.42 & .70 \\
EID & 24 & 1.00 & 5.00 & 3.73 & 0.62 & .92
\end{tabular}

Note: EAS-PT = Environmental Action Scale - Portuguese version;

EBS $=$ Environmental Behaviour Scale; EID = Environmental Identity; NEP = New

Ecological Paradigm

Table 2. Discrimination index of EAS-PT items.

\begin{tabular}{lll}
\hline Item & & $D I$ \\
\hline 1. Educated myself about environmental issues (e.g., through & .60
\end{tabular}
media, television, internet, blogs, etc.).

2. Participated in an educational event (e.g., workshop) related to $\quad .79$ the environment.

3. Organized an educational event (e.g., workshop) related to $\quad .77$ environmental issues.

4. Talked with others about environmental issues (e.g., spouse, $\quad .61$ partner, parent(s), children or friends).

5. Used online tools (e.g., YouTube, Facebook, Wikipedia, MySpace Blogs) to raise awareness about environmental issues.

6. Used traditional methods (e.g., letters to the editor, articles) to $\quad .71$ raise awareness about environmental issues.

$\begin{array}{ll}\text { 7. Personally wrote to or called a politician/government official } & .74\end{array}$ about an environmental issue.

8. Became involved with an environmental group or political party .80 (e.g., volunteer, summer job, etc.).

9. Financially supported an environmental cause.

$\begin{array}{ll}\text { 10. Took part in a protest/rally about an environmental issue. } & .77\end{array}$

11. Organized an environmental protest/rally.

12. Organized a boycott against a company engaging in .54 environmentally harmful practices.

13. Organized a petition (including online petitions) for an environmental cause. 


\begin{tabular}{ll}
\hline Item & $D I$ \\
\hline $\begin{array}{l}\text { 14. Consciously made time to be able to work on environmental } \\
\text { issues (e.g., working part time to allow time for environmental }\end{array}$ & .77 \\
pursuits, working in an environmental job or choosing & \\
environmental activities over other leisure activities). & \\
15. Participated in a community event which focused on & .75 \\
& environmental awareness. \\
16. Organized a community event which focused on environmental & .72 \\
& awareness. \\
17. Participated in nature conservation efforts (e.g., planting trees, & .70 \\
& restoration of waterways). \\
18. Spent time working with a group/organization that deals with the .68 \\
connection of the environment to other societal issues such as \\
justice or poverty.
\end{tabular}

Table 3. Correlations between EAS-PT and other scales.

\begin{tabular}{lllll}
\hline & EAS & EBS & NEP & EID \\
\hline EAS & 1 & $.593^{* *}$ & $.248^{* *}$ & $.452^{* *}$ \\
EBS & & 1 & $.357^{* *}$ & $.548^{* *}$ \\
NEP & & & 1 & $.452^{* *}$ \\
EID & & & & 1 \\
\hline
\end{tabular}

Note: $* * p<.001$

Tabla 1. Estadísticos descriptivos para las escalas.

\begin{tabular}{lcccccc}
\hline Escala & N ítems & Mínimo & Máximo & $M$ & $D T$ & $A$ \\
\hline EAS-PT & 18 & 0.00 & 3.94 & 0.76 & 0.75 & .93 \\
EBS & 11 & 1.18 & 5.00 & 3.43 & 0.75 & .83 \\
NEP & 15 & 2.87 & 5.00 & 4.00 & 0.42 & .70 \\
EID & 24 & 1.00 & 5.00 & 3.73 & 0.62 & .92 \\
\hline
\end{tabular}

Nota: EAS-PT = Environmental Action Scale - Portuguese Version, Escala de Acciones Ambientales-versión Portuguesa; EBS = Environmental Behavior Scale, Escala de Conducta Ambiental; EID = Environmental Identity Scale, Escala de Identidad Ambiental; NEP = New Ecological Paradigm, Nuevo Paradigma Ecológico

Tabla 2. Índice de Discriminación de los ítems de la EAS-PT.

\begin{tabular}{ll}
\hline Item & $D I$ \\
\hline 19. Me he educado a mí mismo sobre temas ambientales (a través de .60
\end{tabular}

19. Me he educado a mí mismo sobre temas ambientales (a través de .60 los medios, la televisión, internet, blogs, etc.). 


\begin{tabular}{|c|c|}
\hline İtem & $D I$ \\
\hline $\begin{array}{l}\text { 20. He participado en un evento educativo (por ejemplo, un taller) } \\
\text { relacionado con el medio ambiente. }\end{array}$ & .79 \\
\hline $\begin{array}{l}\text { 21. He organizado un evento educativo (por ejemplo, un taller) } \\
\text { relacionado con el medio ambiente. }\end{array}$ & .77 \\
\hline $\begin{array}{l}\text { 22. He hablado con otras personas sobre temas ambientales (por } \\
\text { ejemplo, marido o mujer, pareja, padre(s), niños, o amigos). }\end{array}$ & .61 \\
\hline $\begin{array}{l}\text { 23. He usado herramientas online (por ejemplo, YouTube, } \\
\text { Facebook, Wikipedia, MySpace Blogs) para aumentar la } \\
\text { concienciación sobre temas ambientales. }\end{array}$ & .69 \\
\hline $\begin{array}{l}\text { 24. He usado métodos tradicionales (por ejemplo, cartas al editor, } \\
\text { artículos) para aumentar la concienciación sobre temas } \\
\text { ambientales. }\end{array}$ & .71 \\
\hline $\begin{array}{l}\text { 25. He escrito o llamado personalmente a un cargo político o del } \\
\text { gobierno sobre un tema ambiental. }\end{array}$ & .74 \\
\hline $\begin{array}{l}\text { 26. Me he implicado con un grupo ambiental o partido político (por } \\
\text { ejemplo, como voluntario, trabajo de verano, etc.). }\end{array}$ & .80 \\
\hline 27. He prestado apoyo económico a una causa ambiental. & .67 \\
\hline $\begin{array}{l}\text { 28. He participado en una protesta o manifestación sobre un tema } \\
\text { ambiental. }\end{array}$ & .77 \\
\hline $\begin{array}{l}\text { 29. He organizado una protesta o manifestación sobre un tema } \\
\text { ambiental. }\end{array}$ & .66 \\
\hline $\begin{array}{l}\text { 30. He organizado un boicot contra alguna empresa que lleva a cabo } \\
\text { prácticas dañinas para el medio ambiente. }\end{array}$ & .54 \\
\hline $\begin{array}{l}\text { 31. He organizado alguna petición (incluyendo peticiones online) } \\
\text { para una causa ambiental. }\end{array}$ & .61 \\
\hline $\begin{array}{l}\text { 32. He sacado tiempo conscientemente para poder trabajar en temas } \\
\text { ambientales (por ejemplo, trabajo a tiempo parcial para tener } \\
\text { tiempo para cuestiones ambientales, tener un trabajo relacionado } \\
\text { con el medio ambiente, o escoger actividades ambientales en } \\
\text { lugar de otras actividades de ocio). }\end{array}$ & .77 \\
\hline $\begin{array}{l}\text { 33. He participado en un evento comunitario centrado en la } \\
\text { concienciación ambiental. }\end{array}$ & .75 \\
\hline $\begin{array}{l}\text { 34. He organizado en un evento comunitario centrado en la } \\
\text { concienciación ambiental. }\end{array}$ & .72 \\
\hline $\begin{array}{l}\text { 35. He participado en actividades para la conservación de la } \\
\text { naturaleza (plantar árboles, conservación de cauces fluviales). }\end{array}$ & .70 \\
\hline $\begin{array}{l}\text { 36. He dedicado tiempo a trabajar con un grupo u organización } \\
\text { relacionado con la conexión al medio ambiente de otras } \\
\text { cuestiones sociales como la justicia o la pobreza. }\end{array}$ & .68 \\
\hline
\end{tabular}

Tabla 3. Correlaciones entre EAS-PT y otras escalas.

\begin{tabular}{lllll}
\hline & EAS & EBS & NEP & EID \\
\hline EAS & 1 & $.593^{* *}$ & $.248^{* *}$ & $.452^{* *}$
\end{tabular}




\begin{tabular}{|c|c|c|c|c|}
\hline & EAS & EBS & NEP & EID \\
\hline EBS & & 1 & $.357^{* *}$ & $.548^{* *}$ \\
\hline NEP & & & 1 & $.452^{* *}$ \\
\hline EID & & & & 1 \\
\hline
\end{tabular}

Nota: ${ }^{* *} p<.001$ 